\title{
Art Therapy Workshop as an Offer for a Young Educator: From the Perspective of an Art Therapist/Theater Therapist
}

\author{
Warsztaty arteterapii oferta \\ dla młodego pedagoga - z perspektywy \\ arteterapeuty/teatroterapeuty
}

\begin{abstract}
Today's educators experience more anxiety, stress and burnout than ever before, which is why there is growing interest of this professional group in art therapy projects that focus on supporting the development of personal and interpersonal skills. Art workshops are in demand in particular among education students, who experience a certain range of emotional stress when they encounter things that astonish them and cause an invigorating shock. Thus, they can understand how to deal with various emotions, both their own and other people's especially when they have deficiencies in this field and they are seeking improvement. As a result, students-future teachers-become more aware of their own strengths and weaknesses and more actively manage their well-being and commitment to self-development.
\end{abstract}

KEYWORDS

art therapy workshop, education student, art therapist, soft skills, creative process, theater therapy

StOWA KLUCZOWE

warsztaty arteterapii, student pedagogiki, arteterapeuta, umiejętności miękkie, proces twórczy, terapia teatralna

SPI Vol. 24, 2021/4

ISSN 2450-5358

e-ISSN 2450-5366

DOI: 10.12775/SPI.2021.4.004

Submitted: 21.09 .2021 Accepted: 16.11.2021

Articles and dissertations 


\section{ABSTRAKT}

W dzisiejszych czasach pedagodzy odczuwaja więcej niepokoju, stresu i wypalenia zawodowego niż kiedykolwiek wcześniej, dlatego wzrasta zainteresowanie tej grupy zawodowej projektami arteterapeutycznymi, które majq na celu wspieranie rozwoju umiejętności osobistych i interpersonalnych. Warsztaty artystyczne sq szczególnie cenione wśród studentów kierunków pedagogicznych, którzy dzięki możliwości spotkania z rzeczami, kłóre mogq ich zadziwić i wywołać ożywczy szok, doświadczają pewnego napięcia emocjonalnego. Dzięki temu potrafiq zrozumieć, jak sobie radzić z różnymi emocjami, zarówno własnymi, jak i cudzymi, zwłaszcza gdy sami posiadaja braki w tym zakresie i chca je zniwelować. Dzięki temu uczniowie - przyszli nauczyciele - staja się bardziej świadomi swoich mocnych i słabych stron oraz aktywniej zarzqdzają własnym dobrostanem i zaangażowaniem w samorozwój.

\section{Introduction}

Today, having high professional competences is becoming essential for people taking up employment. These competences, determined by knowledge, skills and motivation, are subject to a learning process and develop through various experiences. It is believed that certain professional behaviors, such as the ability to maintain greater emotional balance in moments of crisis or doubt, guarantee job stability and contribute to improving the quality of services provided, which is very much expected and required by employers. Competencies are most often understood as properties, powers and goals that an individual's social behavior aspires to, a structure that constitutes individual abilities and characteristics. The explication of the word competence indicates "in a narrower sense, the colloquial understanding of the term, i.e. the scope of powers in a certain area" (Czerepaniak-Walczak 1999: 60). Undoubtedly, the components of a competence are skills, knowledge and personality traits.

In the course of studies, students, not only those studying in the field of education, develop a sense of personal competence, which is understood as a system of beliefs about their own knowledge and skills contained in the questions: what do I know, what can I do, what are my advantages, what are my weaknesses, what are my limitations, and what resources do I have, regardless of my field of 
studies? Contemporary school needs a teacher who is: "a creative, initiative-filled optimist, an excellent educator with reliable knowledge. The teacher is no longer a ready source of information and becomes a guide towards the future" (Strykowski, Strykowska, Pielachowski 2003: 23). The student-future teacher is expected to cultivate emotional resilience, and encouraged to promote self-insight. The ever-deepening and broadening idea of a person responsible for their own development is repeated in most theories on the contemporary educator due to important competences related to the psyche and social skills. Personal and interpersonal competencies include especially communication skills, the ability to work in a team and resistance to stress. It is important that in their extensive educational activities, young education students are equipped from the beginning with a richer repertoire of behavioral remedies than their students, so they can ultimately teach them to wisely decide for themselves, to avoid subservient behavior, and to find ways to show satisfaction, dissatisfaction, objection or acceptance (e.g. in conflict situations) (cf. Wosik-Kawala, Zubrzycka-Maciąg 2013: 7-8).

The various principles of the education process require, especially from novice teachers, a mastery of various types of competences, including soft skills related to psychology and social skills (Konieczna-Kucharska 2015: 232). In addition, the curriculum includes specialist activities aimed at helping children exhibiting various types of developmental and behavioral abnormalities. Support and assistance covers groups experiencing a variety of existential dramas, resulting not only from disease, physical disability, and family problems, but also from social, political, religious, and ethnic conflicts. For a student of education, such tasks must imply the need to learn about a diversity of measures with psycho-pedagogical impact.

Education systems in many countries pay special attention to certain character traits of the educator, such as empathy, resistance to stress and communication skills, which are affected by a variety of experiences and feelings encountered while accompanying another person in the process of change (Glassman, Prasad 2013: 128). The student-future educator should develop both the ability to express feelings in difficult situations and to control them in interpersonal contacts in order to manifest many kinds of sensitivity. Sensitivity is a sort of courage and readiness to engage in self-development. The 
use of art therapy-based methods in working with education students, using the therapeutic values of different art disciplines in the process of influencing their personal and emotional sphere, can be a valuable approach.

Research is being undertaken to evaluate the effectiveness of art therapy in reducing depression, anxiety, stress and improving psychological well-being in university students. A pilot study conducted on students at the Florida State University, USA found that mindfulness-based art therapy with the use of clay helped to significantly reduce anxiety symptoms and cortisol levels in the participants but without significantly reducing perceived stress (Beerse et al. 2019); whereas a study on the effectiveness of visual therapy conducted among students at three international Islamic universities found that from pretest to posttest measurements, the therapy was effective in reducing depression and stress anxiety and in increasing the psychological well-being of the subjects (Hajra, Saleem 2021).

\section{The goals of art therapy}

In the most general sense, art therapy uses a creative process in creating art to improve and enhance the physical, mental and emotional well-being of people of all ages. Here, art provides the means to symbolically express and embody emotions and feelings. In this process, artistic media are used to encourage participants to release their emotions in a way that does not cause negative consequences. The art therapist has the tools and expertise to maintain the therapeutic space of open expression that is most comfortable for a specific person, when they can go beyond what they know in order to react in extraordinary or unpredictable situations. During art therapy workshops, the main tool is conversation, because artistic creation is a type of conversation, where the participants, referring to their own experience, tell a story about a person, their values and understanding of the world. Through activities focused on art and relationships, the workshop provides an opportunity to find oneself in an inner dialogue. Interaction through artistic expression is used in art therapy to promote health in a broad sense, and because methods and techniques that have an impact in many contexts are used, it is possible to apply them in therapy, rehabilitation or prevention (Improta 2005). 
The use of art therapy in work with future educators may have many individual goals. Most often they are targeted at gaining greater confidence and trust in one's own intuition (see Filipiak 2011: 88), in those who, because of overwhelming emotional states and increased anxiety stemming from being undervalued, lack the stimuli that enhance openness to change and new challenges (Hunt, Eisenberg 2010). Because the act of creation gives the opportunity to face all one's fears and uniqueness, it has a positive effect on those involved in it. Art therapists believe that self-esteem increases as a result of exposure to art, which has a significant impact on psychological well-being, self-image and the ability to function in different individual and social contexts. Art therapy workshops offer tasks that require coping with different characters, situations and challenges to expand the social circles around us. "Instead of sitting on the sidelines, criticizing and giving advice, we must dare to go out to people and let ourselves be seen," says Brene Brown (2020: 14). In the various therapeutic approaches to music therapy, visual therapy, theater therapy or bibliotherapy, the range of artistic activities is very diverse, but the most important results involve gaining an understanding of the importance of inner dialogue. Therapeutic theater, for example, uses theatrical techniques with the intention of "removing an individual obstacle or blockades limiting emotionality, thus leading to changes and the discovery of the new or the potential in oneself" (Mitchell 2005: 53). It should be emphasized once again that human creativity has a special place in the deliberate process of creation, because thanks to it, the human being functions efficiently in a dynamic dialogue between the internal and external reality. Creativity allows us to find new aspects of what is commonly known and close, which, according to art therapists, is conducive to a deeper reflection on oneself. It is the creativity of a person that becomes a manifestation of broadly defined health. Art therapists emphasize that if a person does not find channels of expression suitable for them, and if such channels are not safely opened as channels of emotional relief that enable relaxing their defenses, the person will block their creativity and therefore will repeat problem behaviors or experiences. 


\section{From the notes of an art therapist/theatre therapist}

Many workshops gather individuals whose susceptibility to experiencing strong negative emotions and stress reflects less openness to experience and less tolerance of "novelty." Students, for example, emphasize the fear of loneliness, even though they know that this is common for anyone starting a job in a new place. In this case, the goal should be to direct art therapy interventions towards on gaining personal strength to consciously and actively vent such emotions and to modify the view(s) about oneself, however long-term and difficult the task may be. In the course of theatre therapy conducted by the author in collaboration with the Scientific Society of Young Art Therapists, students often experienced how the use of creative artistic activities slowly broke down their defense mechanisms and brought out their real unconscious "self." Afterwards, they reported feeling "more relaxed," "more successful and more confident." They developed the qualities necessary for an educator (cf. Feen-Calligan, Matthews 2016). On the other hand, students who participated in the theater therapy workshop in the course of their second-cycle (degree) studies, repeatedly described how the use of creative artistic activities reflected their perceptions and fears about their future work and at the same time made them ready to meet face to face with various surprising reactions of people.

Confronting with adulthood and with the tasks faced at the start of a professional career always requires specific competences to cope with the difficult situation creating an atmosphere of tension and heightened anxiety in highly frustrated young teachers. What counts then is creativity and positive self-assessment of one's own abilities, communication skills and the ability to work in a group: the factors necessary to tackle such kind of tasks. In the absence of this type of competence, anxiety and fear increase, additional doubts and persistent thoughts and questions arise as to whether I am emotionally ready to face such a challenge and to cope with it on my own. From the perspective of former workshop participants (as shown by the research conducted by the author), dealing with various situations in

1 Records of the students' statements quoted in this article can be found in the evaluation questionnaires and reports stored in the documentation of the Department of Art Therapy, Faculty of Pedagogy and Fine Arts in Kalisz. 
the art therapy process primarily required the search for unconventional solutions, often even an unwise but invigorating idea for new solutions, but above all the ability to think outside the box. It was an antidote to a difficult situation, because it positively affected gaining more self-confidence and, thanks to the use of creative expression, it contributed to an increase in self-esteem. ${ }^{2}$ Artistic work, as we know, provides much information by deepening the understanding of the importance of the meeting with oneself in the inner dialogue, and the commitment to the creative process builds a supportive community, which is characterized by sensitivity to phenomena taking place between people.

According to Harriet Wadeson, the creative process involved in artistic self-expression helps people to become more physically, mentally, and emotionally healthy and functional, to resolve conflicts and problems, to develop interpersonal skills, to manage behavior, to reduce stress, and to handle life (Wadeson 2000). It is not easy to adequately recognize feelings and emotions from one's own point of view, when the quality of one's own observations is affected by unfavorable emotional well-being. Positive emotions, such as joy and curiosity, attract attention and promote insight, while anxiety and fear, especially when they are long-term, interfere with concentration and hinder thinking. For future educators, a focus on mental and emotional well-being can effectively enhance resistance to stress, a feeling that not only reduces passions and self-confidence, but brings about a number of health problems, including cardiovascular disease and depression.

Certainly, many students will find it easy to write various therapeutic stories or therapeutic fairy tales for children, efficiently defining their goals and depicting the course of events. In their role of participants of art-therapy workshops, they face their own stories, more or less true, but always very important to them. In evaluation surveys

2 The pilot studies that I carried out to design methodological aspects of project activities and the use of art therapy tools for the improvement of the system of vocational training of highly qualified specialists, psychologists and educators. This international project was entitled Developing key competences, important for future teachers and therapists in the field of education and professional help, and was carried out as part of the International Scientific and Methodological Seminar at the Faculty of Pedagogy and Fine Arts in Kalisz and at the Belarusian State University BGU, Faculty of Humanities in Minsk in 2014. 
at the end of the cycle of art therapy workshops, they often just write: "the work on the role gave me a good kick to express my restless emotions," "I think that I worked out a lot myself"; "I strongly believe that my effort was worth it"; "I don't really know what to write because we just had fun and it was fantastic with people," "I thought about a lot, but mostly what I am capable of and what I can do myself!"; "this time enabled me to replenish my largely lost energy"; "I am calmer without the tormenting thought that the world will fall in two if I can't do something-I just don't know something!!!!!”; “especially improvising and understudying made it easier for me to identify similarities in emotions"; "feeling empathy with other participants in the workshop gave me relief" "the most? ... Can I face my self-esteem?"; "it did not increase my sense of belonging but I impressed myself when I was doing something completely spontaneously"; "I accepted a lot despite the fact that I have and had a problem with touch or eye contact"; "the number one benefit was working with the body," "sensory activity; the greatest personal success is the discovery of my corporeality, I have been blocked since primary school."3

A certain type of communication brought about in the process of joint creation unconditionally correlates with a safe environment and can be used to increase relational activity. Zbigniew Nęcki says that "good communication is a way of speaking and listening that enables mutual understanding, and, in favorable conditions, leads to consensus in problem solving" (Nęcki 2000: 75). According to this thesis, communication consists in passing on information in order to achieve a comparable understanding of the content, as well as to achieve a higher level of cooperation. In art therapy workshops offered to young educators, the main goal could be a conscious growth in change, which - thanks to therapeutic activity based on the language of symbols-would enhance the efficiency of expressing the concepts and ideas that young teachers may find difficult to convey through words. For example, art therapy workshop meetings start with looking at things in a way that the person has never experienced

3 Statements written down from the evaluation questionnaires of students of Early Childhood Education with Art Therapy, 1st year master's studies, theatre workshop classes conducted by the author. All questionnaires are kept in the author's documentation/questionnaire, February 2019, Faculty of Pedagogy and Fine Arts, AMU in Kalisz. 
or known before, which in turn enables a satisfactory change in their perception of themselves. In theatre therapy, the existence of information and its processing taking place in the language of theatrical signs is—as Joanna Rutkowiak defines it—a thought in motion, where "what comes to the fore is not the problem as a cognitive task, but perplexity as the most general principle of experience" (Rutkowiak 1992: 27).

We must notice the role of animated negotiations that occur when transcoding one type of signs into another kind, preferred by the recipient, in order for them "to be transmitted in a different code thanks to a great variety of suggested means of expression, e.g. an image, sound configuration, motor spatial exemplification, theatre" (Krasoń, Mazeba-Domagała 2005: 16).

An example of the experience gained from art therapy workshops is a statement presented below on the personal perception of the world in the language of creative expression.

An exercise that I will probably remember for the rest of my life was one of the first exercises in which we were lying on the floor and tracing the contours of our bodies with chalk. I felt how some cosmic white piece of lime curved above my head, wrapped around my arms, touched my legs. At that time, I could imagine what I looked like then from a bird's eye view, and at the same time I felt that the lines drawn with chalk were pressing me into the floor, creating a stigma of my person on it. I became aware of the shape of my body on the floor, so after getting up I was able to accurately resume the previous position. However, what was the most valuable, most moving and fruitful up to a breaking point for me was abandoning the pattern that I had drawn. At one point you said, "erase the pattern, abandon it, you don't have to live in it." For me, this experience was actually real and liberating through and through. While erasing the white lines surrounding my person, I felt a strange fear at first, which soon gave way to some unimaginable euphoria, overwhelming joy. I succumbed to this exercise completely; It was not that I took it seriously (I don't know what happened there anymore), but it was the exercise that took over me, hit my sensitivity, some complex, my unconscious need. When I got up from the floor, I was someone a bit different. Not for others, but mainly for myself.

I think that theater therapy turned out to be quite a therapy for us as a group of people. Previously, I had the impression that we are in each other's company a bit accidentally, everyone has their own circles in which they feel best and our classes are a kind of unpleasant necessity. We were closed to each other, indifferent. During the classes, we 
underwent a complete, real and, literally tangible metamorphosis. I am impressed with how a group of complete strangers could become one living body in a few weeks (I hope it did not sound positivist). I can't find words to express how badly we needed it. Of course, I can only write on my behalf, but I can feel and see that the rest think the same. I do not remember that I felt so well in any group, completely accepted, on the spot, experiencing some kind of unity of thoughts and passion. In life, you can get to know someone by what they tell us about themselves or by observing their behavior. During the classes, people let me get to know them in an unadulterated way; even while playing, they were themselves in a strange way. It was the strangest and at the same time the most effective way to meet a person that I have experienced in my life.

After the course of classes, I found out one more thing about myself: goodness, I have a body! And I can use it as much as I want, and sometimes even let it take precedence over my reason, which in my case takes the form of an ever-punishing policeman. It is indeed strange and sad that I didn't realize it until the age of twenty-three, but better late than never. I did not know that the awareness of the body is so important in a person's life and their relationships with others, or rather in feeling good with oneself. The classes enabled me to establish a thread of liking between my body and soul, which so far have fought each other and remained in constant conflict. ${ }^{4}$

The art therapist selects the means of artistic expression and creates conditions conducive to achieving the therapeutic goal in accordance with the prior diagnosis of the participant's needs. As a consequence of thorough diagnosis, a therapeutic interaction for young educators experiencing emotional and psychological challenges in achieving personal well-being could well serve to improve the level of personal competences, important for their professional functioning. It can offer a safe array of customized artistic techniques to give you the opportunity for the change that discovering your personal resources can bring or the value of an artistic impulse stimulating with the language of a metaphor to use a symbolic code to externalize (describe) certain thoughts and emotions, which in such a safe way may become a record of someone's experience. It is also worth emphasizing the importance of joint observation of the creative process, thanks to

4 The statement is quoted with the consent of the author, the first-year fulltime second-cycle student of Polish Studies, majoring in: Literary and Performative Aesthetics of Adam Mickiewicz University, participant of the theater therapy workshop that I conducted in Poznań in 2012, theater hall. 
which students may have the opportunity to characterize what happened in their own private way. Thanks to this, it becomes possible to find meanings and implications for oneself. An explanation close to the individual reading of the meanings contained in it teaches you to express yourself with a focus on communicating personal experiences. A hermeneutic act is created, which "consists in the full meeting of the world of the author of the sign with the world of the recipient thereof on the plane of the sign, on the basis of which — through the identity of the personal and spiritual structure - a person can recreate the identity of the meaning and function of the sign in appropriate conditions" (Krason 2002: 24). In this case, the author of the sign is both the sender and the recipient of the message.

Below are presented short quotations, selected from all the statements of teacher education students about the performance closing the workshop named "Playing of the rain or searching for rhythms in oneself," taking place on several levels of interpretation: social, therapeutic and artistic. $^{5}$

The personal reflections of the participants were as follows:

- "I was impressed by the emotions that the theatre task was able to evoke, which in my case was to "knit a piece of a sweater out of invisible threads, pulled out or unstitched? from a huddled figure on stage - all at a frenetic pace, to lively music - it was so simple and so incredibly surprising that I thought about it for a long time and it really gave it some personal though not easy insight";

- "being in the process of the game provokes direct reflections "is this how you can see it? I do not know where this understanding came from, but maybe you can read it differently, but together?"

- "the quality of the performance was less important than the interactivity between our ideas and the stage renderings of the theme";

- "the process of the play provokes memory reactions, or maybe it is memory reactions that change the meaning of improvisation"

- "learning the mechanisms of work in a task group";

- "during the game- the opportunity to see the problem through the eyes of the character and then experience what others feel when they see me in action: it all gives a great starting point for discussions and other activities";

5 Statements of part-time students of Pedagogy, majoring in Early Child Education with Art Therapy, Faculty of Pedagogy and Fine Arts, Kalisz on the performance "Rain playing or searching for rhythms in oneself" (EWA 3rd year, part-time studies, 1st semester, May 2010). Quoted with the consent of the participants. 
- "thanks to the fictional nature of the situation and the fact that once I was in the role and then observed everything from outside the role, I could feel from a distance how difficult it is to communicate, how we get confused, how we read other people's motivations, and how we often wrongly show our desires";

- "it is good that in the process of the game, in pretending, in a pretend world, people can talk in conflict and about conflicts, about dreams."

Finally, a summary statement said that: ${ }^{6}$

"We tried to respond to situations, by drawing ideas from our own observations and experiences. To touch the problems of modern man. To go out to and share our feelings with them. Working on the performance allowed us to better understand ourselves and our reactions, to look at people more globally. To open up to others and release emotions that were often deeply hidden. As the workshop participants claim, apart from great fun, hard work and emotional commitment, they acquired the ability to read and listen to themselves."

\section{Psychological and pedagogical support and more ...}

One of the important tasks of contemporary school is to provide psychological and pedagogical support to students with difficulties. The educator's work to improve the dysfunctional behavior of students and to eliminate aggressive behaviors or violence in schools is likely to correspond with the expectation of a change in people's relationships and personality determinants of learning: the deepening of faith in your own abilities, elimination of fear of failure, awakening of positive perception of one's own efficiency. The proposal to employ art therapy workshops as a method of artistic intervention in solving students' problems could also be aimed at strengthening the young teacher in the context of the challenges associated with this complex task (see Karkou 2010; Moriya 2000; Nelson 2010). In the art therapy workshop, both educators and disciples should be prepared for and open to diversity, as artistic activity always entails a considerable amount of information about the performer. Workshops designed

6 A statement by the author of "Teatr bez klamek - art therapy workshop," Sylwia Majcher, included in her thesis entitled "Improvisation in contemporary dance as a form of artistic expression by young people" written under the supervision of the author. 
with this in mind offer therapeutic, aesthetic and educational value and they are in line with the desire to transform one's life, which could be termed as creative self-realization. Encouraging young educators to participate in music therapy, theatre therapy, bibliotherapy or dance and movement therapy should enable them to be reasonably spontaneous and productive and to create circumstances in which they will be able to showcase their skills and abilities, even if this is related to some kind of chaos, randomness, or a temporary departure from the mainstream. This may be a good example of an option for those students who, despite being full partners in conversation or discussion, have difficulty expressing their thoughts and feelings, preferring to avoid some of the people and the relationships with them. Such experiences can result in an increase in a sustained level of frustration, stress or anger. In order to prevent such reactions in an educator, art therapists promote understanding of different narratives, which here and now take place in the presence of the two experiencing entities (me and you), and in such a way that everyone feels accepted and unjudged. Learning the techniques of dialogue using the language of art provokes treating such a conversation as a way of being, but entitling each creator to make mistakes, to exceed their limitations and to reject excesses in order to return to oneself in greater harmony and greater awareness of what they have at their disposal. A cheerful atmosphere or relaxation (e.g., to increase resistance to stress) is in fact meant to strengthen these moments and spaces that support students in their search for unique experiences in the creative process with the use of the non-verbal language or other means of artistic expression. In conditions conducive to the creative act of communication, quite often in the form of ordering the facts and events in a narrative, the student can uncover what he or she does not want to or cannot express yet. In the creative process, means of expression become a bridge between different parts of the "self" and require thoughtfulness from engaged consciousness. Work on such a process should then remain more symbolic, with metaphorical interpretations and some verbal associations or analogies. What matters is the student's openness to introspection and reflection, focused on examination of the issue considered important by and for all co-participants. The benefits identified in art therapy activities are ultimately related to increased awareness of the self and acquisition 
of strengths that block the cut-and-dried images and understanding of reality. For example, during theater therapy, the artistic language may combine various features of the theater and fine arts or musical happening, so that by means of the body or gestures, through the modeling of various materials, the use of dance, rhythms, sounds or theater games, at a given moment, the participant satisfies their psychological need for support, relaxation, challenge or reflection. Each of the materials carries different messages that support understanding and control over what is recognized and what can trigger the socalled effective surprise described by Jerome Seymour Bruner (Bruner 1979: 14, 18-19).Certainly, many students of education may find it interesting to include in the therapeutic space activities they know from methodology classes dedicated to artistic work with children: dancing, movement, singing, creative writing, role-playing, painting etc., and which they recognize as bait cast in order to listen to emotions that live within themselves. Undoubtedly, the ability to perceive and interpret one's own and other people's emotions is affected by internal and external factors that shape self-esteem in experiences. Creative activities can be an engine of both conscious and unconscious needs of an individual who, as a creator, is the most perfect material for building a strong concept of the self. In the art therapy process, facilitating self-perception from a different, sometimes new, perspective often corresponds with a surprising recognition of emotions and the consequence of their precise definition. In this situation, the art therapy workshop proposes a safe confrontation with the source of internal tension, often expressed as a state of pain, fear, anxiety or apathy. Frequently, underestimation is combined with undervaluation of one's own strengths and potentials as well as lower self-confidence. Conversation in the language of art helps develop emotional vocabulary, which for a young educator may (though not necessarily) be useful to specify the impressions from experiences inspired by creative activities or to better understand, for example, the mechanisms of coping emotional behaviors and to describe the way of dealing with unpleasant situations.

By experiencing individual differences in perception and creative expression, a young adept in the art of teaching and learning can more flexibly approach the otherness of views, attitudes, thinking and behaviors of different people so as to experience more and 
more understanding of their meanings. This is an immensely useful soft competence in the teaching profession. Thanks to such skills, the reading of needs or interpreting one's own and other people's behaviors draws on the way we perceive, read, segregate or compare our experiences. University students, including future teachers, are exposed to daily stressors during their academic career, which can have lasting consequences for their health and well-being. Doing artistic and creative activities in the presence of an experienced art therapist can help each of us process our emotions better, learn more about ourselves, and gain a sense of calm.

\section{Bibliography}

Brown B. (2020). Gifts of Imperfection, London: Vermilion.

Bruner J.S. (1979). On Knowing: Essays for the Left Hand, Cambridge (MA): Harvard University Press.

Beerse M.E., van Lith T., Gregg D., Stanwood D.G. (2019). "Is There a Biofeedback Response to Art Therapy? A Technology-Assisted Approach for Reducing Anxiety and Stress in College Students," SAGE Open, vol. 9, April-June, pp. 1-12.

Czerepaniak-Walczak M. (1999). "Kompetencja. Słowo kluczowe czy „wytrych” w edukacji?” Neodidagmata, vol. 24, pp. 53-66.

Feen-Calligan H., Matthews W.K. (2016). "Pre-Professional Arts Based Service-Learning in Music Education and Art Therapy," International Journal of Education E the Arts, vol. 17, no. 17, pp. 1-36.

Filipiak E. (2011). Z Wygotskim i Brunerem w tle. Stownik poję́ kluczowych, Bydgoszcz: Wydawnictwo Uniwersytetu Kazimierza Wielkiego.

Glassman E.L., Prasad S. (2013). "Art Therapy in Schools: Its Variety and Benefits," in P. Howie, S. Prasad, J. Kristel (eds.), Using Art Therapy with Diverse Populations: Crossing Cultures and Abilities, London-Philadelphia (PA): Jessica Kingsley Publishers, pp. 126-134.

Hunt J., Eisenberg D. (2010). "Mental Health Problems and Help-Seeking Behavior among College Students," Journal of Adolescent Health, vol. 46, no. 1, pp. 3-10.

Improta A. (2005). Art Therapy - The Art of Curing, Firenze: PsicoLAB.

Karkou V. (2010). Arts Therapies in Schools: Research and Practice, London: Jessica Kingsley.

Konieczna-Kucharska M. (2015). "Miękkie i twarde kompetencje nauczycieli," Zeszyty Naukowe Politechniki Czesstochowskiej. Zarzadzanie, no. 19, pp. 229-241.

Krasoń K. (2002). "Dziecko czyta i przetwarza tekst," Edukacja i Dialog, no. 7, pp. 23-27. 
Krasoń K., Mazepa-Domagała B. (2005). Przestrzenie sztuki dziecka. Strategia intersemiotycznego i polisensorycznego wsparcia jednostek o obniżonej sprawności intelektualnej, Katowice: Librus.

Mitchell S. (1992). „Therapeutic Theatre,” in S. Jennings (ed.), Dramatherapy: Theory and Practice 2, London-New York: Routledge, pp. 51-67.

Mitchell S. (2005). "Theatre of Self-Expression - A 'Therapeutic Theatre' Model of Dramatherapy," in S. Jennings, A. Cattanach, S. Mitchell, A. Chesner, B. Meldrum (eds.), The Handbook of Dramatherapy, London-New York: Routledge, pp. 41-57.

Nelson C.L. (2010). "Meeting the Needs of Urban Students: Creative Arts Therapy," Journal of the American Art Therapy Association, vol. 27, no. 2, pp. 62-66.

Nęcki Z. (2000). Negocjacje w biznesie, Kraków: Antykwa.

Rutkowiak J. (1992). "O dialogu edukacyjnym. Rusztowanie kategorialne," in J. Rutkowiak (ed.), Pytanie, dialog, wychowanie, Warszawa: Wydawnictwo Naukowe PWN.

Strykowski W., Strykowska J., Pielachowski J. (2003). Kompetencje nauczyciela szkoty wspótczesnej, Poznań: Wydawnictwo eMPi².

Wadeson H. (2000). Art Therapy Practice: Innovative Approaches with Diverse Populations, New York: John Wiley \& Sons.

Wosik-Kawala D., Zubrzycka-Maciąg T. (eds.) (2011). Kompetencje diagnostyczne i terapeutyczne nauczyciela, Kraków: Oficyna Wydawnicza „Impuls”.

\section{Netography}

Hajra B., Saleem T. (2021). "The Use of Islamic Patterned Art Therapy: Healing of Psychological Problems Among University Students," Journal of Religion and Health, vol. 60, pp. 4361-4386, https://rdcu.be/ cxWz9 [access: 10.08.2021].

Moriya D. (2000). Art Therapy in Schools: Effective Integration of Art Therapists in Schools, Ramat Hasharon: D. Moriya, https://www.amazon.com/ Art-Therapy-Schools-Integration-Therapists/dp/9659034415 [access: 09.08.2021].

\section{ADDRESS FOR CORRESPONDENCE}

Anita Stefańska

Adam Mickiewicz University in Poznań

Faculty of Pedagogy and Fine Arts in Kalisz

e-mail: as123@amu.edu.pl 